\title{
ANTIGEN RECOGNITION BY IGG4 ANTIBODIES IN HUMAN TRICHINELLOSIS
}

\author{
PINELLI E.*, VAN DER LUGT G.*, HOMAN W.**, VAN DER GIESSEN J.*** \& KORTBEEK L.M.*
}

\section{Summary :}

The antibody isotype response to Trichinella spiralis excretory/secretory (ES) products of muscle larva was examined using sera from patients with confirmed trichinellosis. Using Western blots we identity components of the ES antigen that are recognized by $\lg M$ and $\lg G$ antibodies. A $45 \mathrm{kDa}$ component was strongly recognized by different antibody classes and subclasses. We observed a $45 \mathrm{kDa}$-specific lgG4 response that was detected exclusively using sera of patients with trichinellosis and not of patients with echinococcosis, filariasis, cysticercosis, ascariasis, strongyloidiasis or toxocariasis. These results are relevant for the diagnosis of human trichinellosis.

KEY WORDS : human trichinellosis, ES antigen, 45 kDa, lgG4 onitoring programs for detection of trichinellosis in slaughterhouse animals have dramatically decreased the incidence of human trichinellosis. However, in many parts of the world, including Europe, it continues to occur. Recent outbreaks of trichinellosis have been reported from Germany, France, Spain and Italy (Ancelle et al., 1998; Rodriguez et al., 1999); (Pozio 1998).

In our laboratory the immunodiagnosis of trichinellosis is performed by using an enzyme-linked immunosorbent assay (ELISA) in which the excretory/secretory (ES) products of Trichinella spiralis muscle larvae are used as antigen (van Knapen et al., 1982). Analysis of this ES antigen by SDS-PAGE revealed that this antigen comprises a complex mixture. The use of this antigen in an ELISA may give rise to false-positive results due to the presence of antigenic components shared with

\footnotetext{
* Diagnostic Laboratory for Infectious Diseases and Perinatal Screening, National Institute of Public Health and the Environment (RIVM), Bilthaven, The Netherlands.

${ }^{* *}$ Research Laboratory for Infectious Diseases, National Institute of Public Health and the Environment (RIVM), Bilthaven, The Netherlands.

${ }^{* * *}$ Microbiological Laboratory for Health Protection, National Institute of Public Health and the Environment (RIVM), Bilthoven, The Netherlands.

Correspondence : Dr. Elena Pineli. Dept. of Parasitology and Mycology, LIS, National Institute of Public Health and the Environment (RIVM), P.O. Box 1, 3720 BA Bilthoven, The Netherlands.

Tel. : 31-30-2744277 - Fax: 31-30-2744418

E-mail : elena.pinelli@rivm.nl
}

other helminths. Therefore, to confirm results from the ELISA we introduced the Western blotting technique. Identification of parasite antigens recognized by different antibody classes and subclasses can be a valuable tool for the immunodiagnosis of helminth infections (Magnaval et al., 1991; Gadea et al., 1999). We observed that the IgG4 response directed to a $45 \mathrm{kDa}$ component of ES products of muscle larva was Trichinella-specific. The measurement of this response can be used for the immunodiagnosis of trichinellosis.

\section{MATERIALS AND METHODS}

\section{ANTIGENS}

The excretory/secretory (ES) antigen was prepared using viable muscle larva of $T$. spiralis as previously described by Gamble (1985). The 45 $\mathrm{kDa}$ antigenic component was purified from freshly obtained muscle larva using two-step affinity chromatography as described by Homan et al. (1992)

\section{SERUM SAMPLES}

Serum samples from trichinellosis patients recently received at our laboratory and from an outbreak of trichinellosis that took place in Slupsk, Poland in 1991 were used in this study. The patients here studied were all at an early stage of trichinellosis. All serum samples used tested positive for IgM and/or IgG by means of ELISA using T. spiralis ES antigen. Infection was confirmed for several patients from the outbreak in Poland and for the other patients used in this study by identification of Trichinella larva in muscle biopsy. The source for T. spiralis infection for the outbreak was undercooked pork. Sera from our laboratory from echinococcosis, filariasis, cysticercosis, ascariasis, strongyloidiasis or toxocariasis patients were also included.

\section{WESTERN BLOTTING PROCEDURE}

The ES antigen or the $45 \mathrm{kDa}$ protein was solubilized under reducing conditions and electrephorized on 
$10 \%$ polyacrylamide gels in SDS according to Laemmli (1970). For Western blot analysis, antigens were electroforetically transferred onto nitrocellulose membrane according to the procedure of Towbin et al. (1979). Blots were incubated at $4^{\circ} \mathrm{C}$ overnight in $0.05 \%$ Tween 20/phosphate-buffered saline (PBS/Tween) containing $1 \%$ low fat milk (Protifar, Nutricia). Immunodetection was performed by incubation of the blots with serum samples diluted in $0.05 \% \mathrm{PBS} /$ Tween containing $1 \%$ low fat milk. After sequential washing with PBS/Tween the blot was incubated with peroxidase conjugated monoclonal antibodies directed to the various $\operatorname{IgG}$ subclasses (CLB, The Netherlands) or with peroxidase conjugated goat anti-human IgM and IgG (Sigma). Conjugated antibodies were diluted in PBS/Tween containing $1 \%$ low fat milk. After washes in PBS/Tween, tetramethyl benzidine/di-octyl-natriumsulpho-succinate (TMB/DONS, $0.06 \%$ and $0.2 \%$, respectively in Dimethyl sulfoxide, DMSO) was added as substrate.

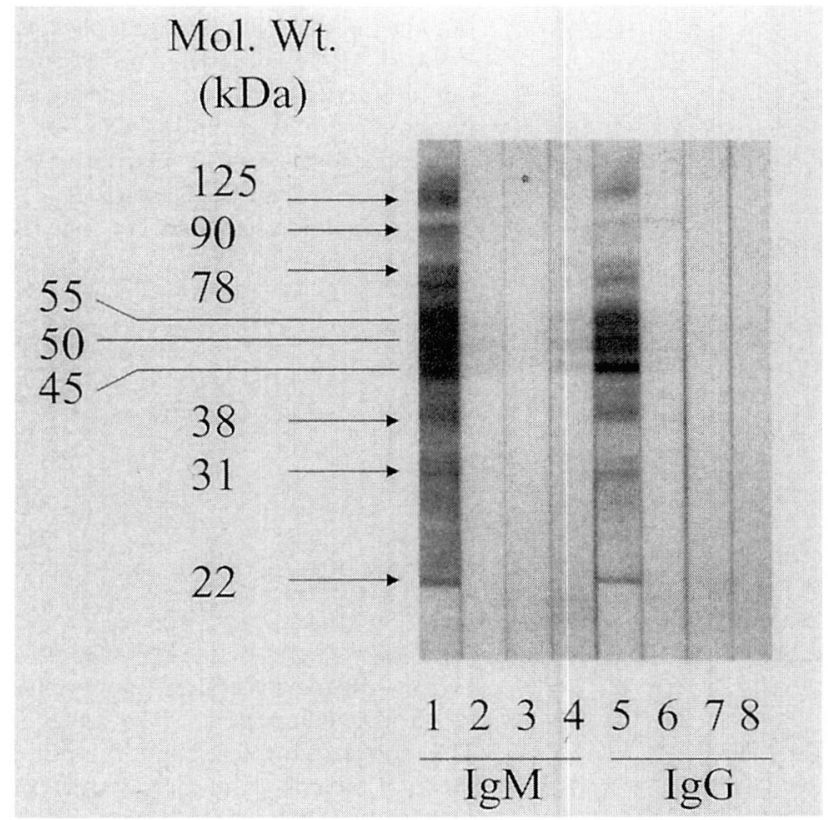

FIG 1. - Western blot revealing bands recognized by Trichinella-specific IgM and IgG antibodies. The ES antigen electrephorized on 10 $\%$ polyacrylamide gels in SDS was electroforetically transferred to nitrocellulose membrane. Indicated by arrows are the specific bands with molecular weight (Mol. Wt.) of $125 \mathrm{kDa}, 90 \mathrm{kDa}, 78 \mathrm{kDa}, 38$ $\mathrm{kDa}, 31 \mathrm{kDa}$ and $22 \mathrm{kDa}$ recognized by IgM (lane 1 to 4 ) and total IgG (lane 5 to 8 ) in serum from a trichinellosis patient from the outbreak that took place in Poland in 1991 (lane 1 and 5). Also indicated by lines are bands of Mol. Wt. $45 \mathrm{kDa}, 50 \mathrm{kDa}$ and $55 \mathrm{kDa}$ which are recognized by $\operatorname{IgM}$ and $\operatorname{IgG}$ in sera of trichinellosis patients but are also ocassionally recognized by antibodies from other helminth infected patients (lane 4); echinococcosis (lanes 2 and 6), filariasis (lane 3 and 7), cysticercosis (lane 4 and 8).

\section{RESULTS}

\section{WESTERN BLOT ANALYSIS OF IGM AND IGG REACTIVITY TO ES ANTIGEN}

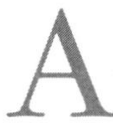
nalysis of Western blots using T. spiralis-ES antigen indicates a specific banding pattern represented by bands of $125 \mathrm{kDa}, 90 \mathrm{kDa}$, $78 \mathrm{kDa}, 38 \mathrm{kDa}, 31 \mathrm{kDa}$ and $22 \mathrm{kDa}$ that are recognized by IgM and IgG antibodies present in sera from a Trichinella-infected patient (Fig. 1). Bands of $45 \mathrm{kDa}$, $55 \mathrm{kDa}$ and $58 \mathrm{kDa}$ recognized by $\mathrm{IgM}$ and total $\mathrm{IgG}$ antibodies of trichinellosis patients appeared occasionally using sera from patients with other helminth infections. We observed however, that IgM and total IgG antibodies present in sera from T. spiralis-infected patients reacted strongly to a $45 \mathrm{kDa}$ antigenic component. The IgG response to this component was predominantly of the IgG1 and IgG2 subclass with a minor IgG3 response. Interestingly, a clear $45 \mathrm{kDa}$-specific IgG4 response was detected (Fig. 2). Therefore, we became interested to investigate further the parasite-specific IgG4 response of patients with trichinellosis.

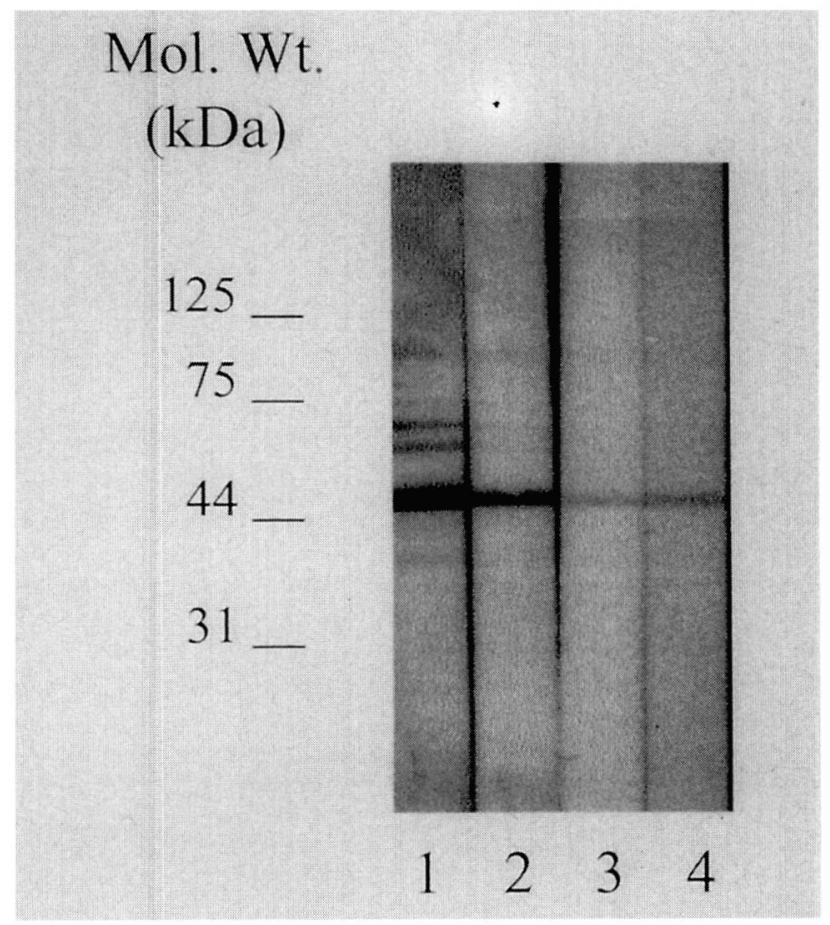

FIG 2. - Reactivity of IgG subclass antibodies to $45 \mathrm{kDa}$ component of ES antigen. A partially purified fraction of the component of ES antigen with a molecular weight (Mol. Wt.) of $45 \mathrm{kDa}$ was electrophorized on $10 \%$ polyacrylamide gels in SDS was electroforetically transferred to nitrocellulose membrane. Indicated are results using serum from a trichinellosis patient from the outbreak that took place in Poland in 1991; IgG1 (lane 1), IgG2 (lane 2), IgG3 (lane 3) and IgG4 (lane 4). 


\section{RECOGNITION OF ES ANTIGEN BY IGG4 ANTIBODIES}

Fig. 3 shows the recognition of the ES antigen by IgG4 antibodies present in serum samples of trichinellosis patients. The intensity of this response varied from patient to patient and it was detected only when using sera from trichinellosis patients and not from patients with echinococcosis, filariasis, cysticercosis, ascariasis, strongyloidiasis or toxocariasis.

\section{RECOGNITION OF $45 \mathrm{KDA}$ COMPONENT OF ES BY IGG4 ANTIBODIES}

In Fig. 4, the recognition of the $45 \mathrm{kDa}$ component of the ES antigen by IgG 4 antibodies is shown. The intensity of this response varied from patient to patient and it was observed only when using sera from trichinel- losis patients. In contrast, no reactivity was found using sera from echinococcosis, filariasis, cysticercosis, ascariasis, strongyloidiasis or toxocariasis patients. The serum samples used here were the same and in the same order as that described for Fig. 3. Noteworthy is the weak reactivity of IgG4 from patients shown in lane 15 and 16 . However, no reactivity at all was observed using the ES antigen and this same serum samples (Fig. 3).

\section{DISCUSSION}

Tnfection with Trichinella spiralis evokes a humoral immune response, predominantly of the IgM, IgG and IgA classes (van Knapen et al., 1982; Au et al., 1983; Feldmeier et al., 1987). In this study we report

\section{Mol. Wt}

$(\mathrm{kDa})$

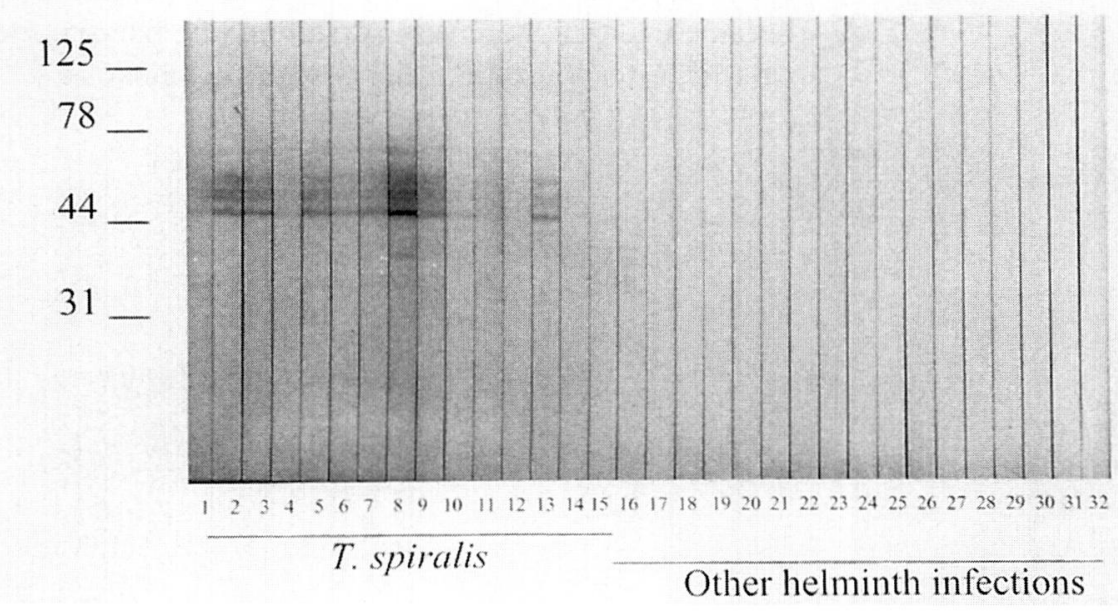

FIG 3. - Reactivity of IgG4 antibodies to ES antigen. The serum samples used included those of patients from the outbreak of trichinellosis taken place in Poland, 1991 (1-10), and serum samples received at our laboratory of patients with trichinellosis (11-15), echinococcosis (16-17), filariasis (1819), cysticercosis (20-22), ascariasis (23$25)$, strongyloidiasis (26-28) or toxocariasis (29-32).

\section{Mol. Wt.}

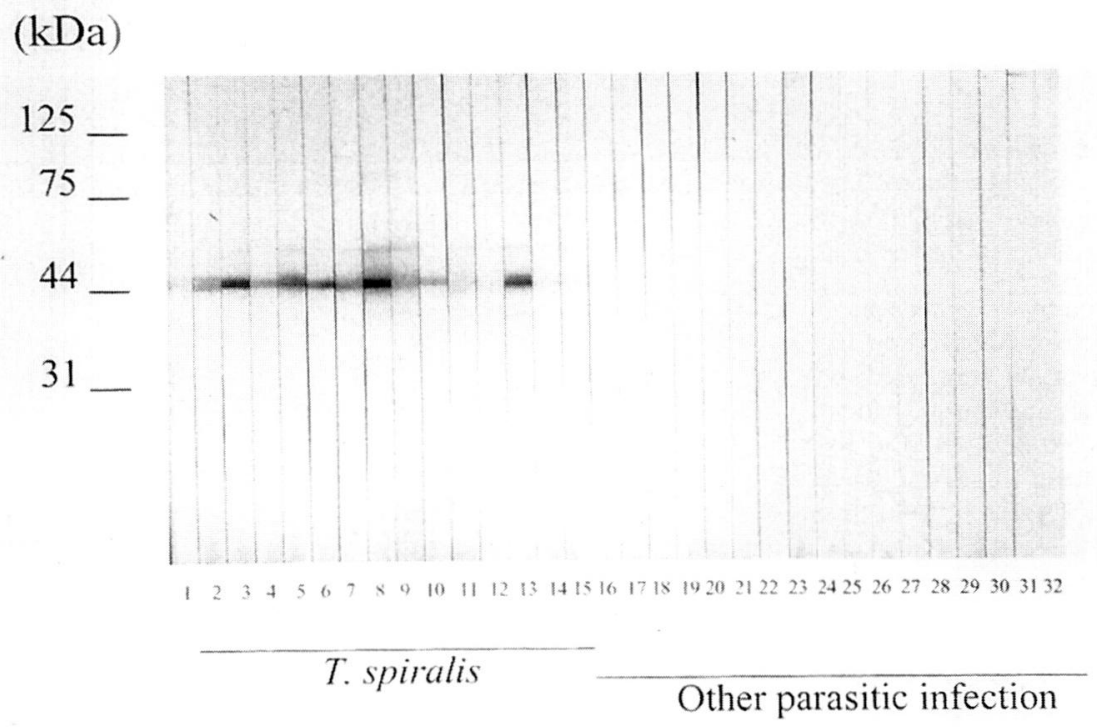

Fig 4. - Reactivity of IgG4 antibodies to $45 \mathrm{kDa}$ component of ES antigen. The serum samples used included those of patients from the outbreak of trichinellosis taken place in Poland, 1991 (1-10), and serum samples received at our laboratory of patients with trichinellosis (11-15), echinococcosis (16-17), filariasis (18-19), cysticercosis (20-22), ascariasis (23-25), strongyloidiasis (26-28) or toxocariasis (29-32). The serum samples used here were the same and in the same order as that described in Fig. 3. 
on the use of Western blots for the identification of component of the ES antigen recognized by IgM and IgG subclasses present in sera of patients at an early stage of trichinellosis.

An interesting result from our study is the detectable IgG4 response directed to a $45 \mathrm{kDa}$ component of the ES antigen. This response was found to be T. spiralisspecific since it was not detected using sera from patients with other helminth infections.

An increase in the production IgG4 during infection with helminths has been previously described (Ottesen et al., 1985; Magnusson et al., 1986). However, increased IgG4 antibody levels has been generally associated with chronic antigenic stimulation (Magnusson et al., 1986; Aalberse et al., 1983).

Detection of IgG4 levels in human trichinellosis has not been extensively studied. However, from an earlier follow-up study it was shown that a significant higher number of IgG4 Trichinella-positive sera were found by means of ELISA, during the chronic stage of infection. The authors suggest that the IgG4 response can discriminate between an early and a late infection with T. spiralis (Ljungstrom et al., 1988). By identifying the target antigens of IgG4 and using a purified a fraction of one of these antigens we observed that using Western blots, this response could also be detected during an early stage of trichinellosis. Taking together, monitoring the $45 \mathrm{kDa}$-specific IgG4 response can be a valuable tool for the immunodiagnosis of human trichinellosis.

\section{REFERENCES}

Aalberse R.C., van Der G.R. \& van Leeuwen J. Serologic aspects of IgG4 antibodies. I. Prolonged immunization results in an IgG4-restricted response. J. Immunol., 1983 , $130,722-726$.

Ancelle T., Dupouy Camet J., Desenclos J.C., Maillot E., Savage Houze S., Charlet F., Drucker J. \& Moren A. A multifocal outbreak of trichinellosis linked to horse meat imported from North America to France in 1993. Am. J. Trop. Med. Hyg., 1998, 59, 615-619.

Au A.C., Ko R.C., Simon J.W., Ridell N.J., Wong F.W. \& TemPLER M.J. Study of Acute Trichinosis in Ghurkas : Specificity and sensitivity of enzyme-linked immunosorbent assays for IgM and IgE antibodies to Trichinella Larval antigens in diagnosis. Trans. R. Soc. Trop. Med. Hyg., 1983, 77, 412-415.

Feldmeier H., Fischer H. \& Blaumeiser G. Kinetics of humoral response during the acute and the convalescent phase of human trichinosis. Zentralbl. Bakteriol. Mikrobiol. Hyg., A., 1987, 264, 221-234.

Gadea I., Ayala G., Diago M.T., Cunat A. \& Garcia de lomas J. Immunological diagnosis of human cystic echinococ- cosis : utility of discriminant analysis applied to the enzyme-linked immunoelectrotransfer blot. Clin. Diagn. Lab. Immunol., 1999, 6, 504-508.

GAMBLE H.R. Trichinella spiralis: Immunization of mice using monoclonal antibody affinity-isolated antigens. Exp.Parasitol., 1985, 59, 398-404.

Homan W.L., Derksen A.C. \& van Knapen F. Identification of diagnostic antigens from Trichinella spiralis. Parasitol. Res., 1992, 78, 112-119.

LAEMMLI U.K. Cleavage of structural proteins during the assembly of the head of bacteriophage T4. Nature, 1970, $227,680-685$.

Ljüngstrom I., Hammarstrom L., KociecKa W. \& Smith C.I. The sequential appearance of IgG subclasses and IgE during the course of Trichinella spiralis Infection. Clin. Exp. Immunol., 1988, 74, 230-235.

Magnaval J.F., Fabre R., Maurieres P., Charlet J.P. \& de LarRARD B. Application of the Western blotting procedure for the immunodiagnosis of human toxocariasis. Parasitol. Res., 1991, 77, 697-702.

Magnusson C.G., Cesbron J.Y., Djurup R., Capron A. \& JOHANSSON S.G. Raised serum IgG4 levels in patients with atopy and filariasis : Application of an automated particlecounting immunoassay using monoclonal antibody. Int. Arch.Allergy Appl. Immunol., 1986. 81, 238-244.

Ottesen E.A., SkVaril F., Tripathy S.P., PoindeXter R.W. \& HusSaIN R. Prominence of IgG4 in the IgG antibody response to human filariasis. J. Immunol., 1985, 134, 2707-2712.

Pozio E. Trichinellosis in the European union: Epidemiology, ecology and economic impact. Parasitol. Today, 1998, 14 , 35-38.

Rodriguez O.M., Abad J.M., de Haro T., Villa R.R. \& Gomez G., V Human Trichinellosis in southern Spain : Serologic and epidemiologic Study. A.J. Trop. Med. Hyg., 1999, 61, 834-837.

Towbin H., Staehelin T. \& Gordon J. Electrophoretic Transfer of proteins from polyacrylamide gels to nitrocellulose sheets: Procedure and some applications. Proc. Natl. Acad. Sci. USA, 1979, 76, 4350-4354.

Van Knapen F., Franchimont J.H., Verdonk A.R., Stumpf J. \& UndeUTSCH K. Detection of specific immunoglobulins (IgG, IgM, IgA, IgE) and total IgE Levels in human trichinosis by means of the enzyme- linked immunosorbent assay (ELISA). Am. J. Trop. Med. Hyg., 1982, 31, 973-976. 